\title{
Sifat Fisik dan Komposisi Kimia Nugget Daging Itik Afkir Curing dalam Ekstrak Kurkumin Kunyit
}

\author{
S. H. C. Dewi ${ }^{1, *}$, C. Wariyah ${ }^{2}$ \\ ${ }^{1}$ Program Studi Peternakan, Fakultas Agroindustri, Universitas Mercu Buana Yogyakarta \\ ${ }^{2}$ Program Studi Teknologi Hasil Pertanian, Fakultas Agroindustri, Universitas Mercu Buana Yogyakarta
}

\begin{abstract}
ABSTRAK
Penelitian ini bertujuan untuk mengetahui sifat fisik dan komposisi kima nugget daging itik afkir curing dalam ekstrak kurkumin kunyit. Daging itik afkir dicuringmenggunakan kurkumin kunyit sebanyak 0,3\% selama 10 menit, kemudian dibuat nugget. Nugget daging itik afkir divariasi dengan penambahan wortel dan brokoli serta nugget tanpan tambahan sayuran. Penelitian ini dilakukan untuk membandingkan secara deskriptif antara nugget daging itik afkir, nugget daging itik afkir ditambah wortel dan nugget daging itik yang ditambah brokoli. Data yang diperoleh dianalisis dengan analisis deskriptif. Hasil pengamatan didapatkan bahwa nugget daging itik dengan penambahan wortel dan brokoli mempunyai warna yang lebih cerah daripada yang daging itik saja. Tekstur nugget yang ditambah brokoli lebih keras daripada yang daging itik dan yang ditambah wortel. Berdasarkan hasil penelitian disimpulkan bahwa nugget daging itik dengan penambahan wortel dan brokoli akan memperkaya komposisi kimia, dengan sifat fisik yang relatif sama.
\end{abstract}

Kata kunci: Komposisi kimia, Sifat fisik, Nugget, Curing, Ekstrak kurkumin kunyit

\section{Physical Properties and Chemical Compositions of Nugget Made from Duck-Meat Cured in Tumeric Curcumin Extract}

ABSTRACT

This study aims were to determine the physical properties and chemical compositions of nuggets made from curedduck meat in turmeric curcumin extract. The duck meat was cured in $0.3 \%$ turmeric curcumin for 10 minutes, and then it was processed into nuggets. The duck-meat nuggets were made with variation on original nugget, nugget with added of carrots and broccoli. This research was conducted to compare descriptively between nugget of duck-meat, nugget of duck-meat plus carrot and nugget of duck-meat plus broccoli. The data obtained were analyzed by descriptive analysis. The observation found that duck-meat nugget with the addition of carrots and broccoli has a brighter color than the duck-meat only. Medium texture plus broccoli was harder than the duck-meat and the added carrots. Based on the results of the study, it can be concluded that the nugget of duck-meat with the addition of carrots and broccoli will enrich the chemical composition, with relatively similar physical properties.

Keywords: Chemical compositions, Physical properties, Nugget, Curing, Turmeric curcumin extract

\section{PENDAHULUAN}

Itik merupakan ternak unggas yang dipelihara untuk menghasilkan telur dan daging. Populasi itik di Indonesia meningkat dari tahun ke tahun, yaitu 45.268.000 ekor (2014), 45.322.000 ekor (2015) dan diperkirakan pada tahun 2016 sebanyak 47.360.000 ekor (BPS, 2016). Dilihat dari peningkatan populasi tersebut, maka perkembangan sangat menjanjikan. Daging itik ini dapat berasal dari itik pedaging maupun itik afkir yaitu itik dari itik petelur yang sudah tidak produktif lagi. Itik betina petelur pada umumnya akan diafkir setelah tidak menguntungkan sebagai penghasil telur. Itik yang telah diafkir ini kemudian dijadikan sebagai itik pedaging. Daging itik yang berasal dari itik afkir mempunyai beberapa kelemahan, antara lain yaitu tekstur liat dan kadar lemak lebih tinggi dari ayam pedaging dan harga jual yang rendah.Kadar lemak daging ayam 1,05\%, sedangkan daging itik afkir mencapai 1,84\% (Ali et

*Penulis Korespondensi: S. H. C. Dewi

Alamat: Jl. Wates KM 10 Yogyakarta 55753

E-mail : candradewisrihartati@yahoo.co.id al., 2007), 2,7 - 6,8 \% (Matitaputty dan Suryana, 2010). Asam lemak tak jenuh (ALTJ) lebih dari 60\% dari total asam lemak, mengakibatkan daging itik mudah teroksidasi yang dapat menurunkan flavor, zat gizi dan menimbulkan zat yang bersifat toksik. Menurut Shahidi (1998) dalam Matitaputty dan Suryana (2010) menyatakan bahwa daging yang mengandung lemak cenderung menghasilkan offflavor yang lebih besar, karena daging tersebut mengandung asam tidak jenug yang lebih besar dan mudah teroksidasi. Sampaio et al. (2012) menyatakan bahwa oksidasi lipid pada daging domba akan berlanjut sampai dengan pengolahan akibat adanya pemanasan.

Kerusakan daging itik afkir akibat oksidasi lemaknya dapat dicegah dengan menambahkan zat yang dapat mencegah atau memperlambat terjadinya oksidasi yaitu antioksidan. Sesuai dengan pendapat Matitaputty dan Suryana (2010) bahwa salah satu cara untuk mengambat oksidasi lemak adalah dengan menggunakan antioksidan, baik sintetik maupun alami. Penggunaan antioksidan alami lebih disukai, karena diyakini aman bagi kesehatan. Berbagai 
penelitian telah dilakukan untuk mendapatkan antioksidan alam seperti pada jahe (Kikuzaki dan Nakatani, 1994), dan teh hijau (Chung et al.,1998; Wanasundara dan Shahidi, 1994; Yokozawa et al., 2002). Menurut Ruslay et al. (2007), kunyit mengandung senyawa bisde-methoxycurcumin, demethoxycurcumin dan curcumin. Senyawa tersebut mampu menghambat peroksidasi asam linoleat, dengan potensi bisdemethoxycurcumin < demethoxycurcumin < curcumin (Jayaprakasha et al., 2006). Menurut Fujiwara et al. (2008), kurkumin sangat potensial sebagai antioksidan. Hasil penelitian Setyowati dan Wariyah (2012) menunjukkan bahwa ekstrak kurkumin mampu meningkatkan menghambat oksidasi lemak. Permasalahannya adalah penyimpanan maupun pengolahan menjadi produk seperti nugge ttidak lepas dari kondisi kontak dengan panas, udara, dan sinar sehingga memungkinkan oksidasi lemak (Baggio dan Bragagnolo, 2006). Dewi dan Astuti (2014) menyatakan bahwa ekstrak kurkumin kunyit mampu menghambat peroksidasi asam lemak daging itik afkir selama penyimpanan dalam freezer.

Menurut SNI (2002) nugget merupakan salah satu produk olahan daging yang dicetak, dimasak dan dibekukan serta terbuat dari campuran daging giling yang diberi bahan pelapis atau tanpa penambahan bahan makanan lain dan bahan tambahan makanan yang telah diizinkan. Nugget merupakan produk olahan daging yang sangat digemari konsumen tanpa memandang golongan dari sisi ekonomi maupun usia. Oleh karena itu, perkembangan nugget baik variasi unsur bahan maupun bentuknya. Produk beku siap saji ini hanya memerlukan waktu penggorengan selama 1 menit pada suhu $150^{\circ} \mathrm{C}$ atau tergantung pada ketebalan dan ukuran produk. bentuk nugget .

\section{MATERI DAN METODE}

\section{Sampel Penelitian}

Bahan yang digunakan untuk penelitian adalah daging itik yang diperoleh dari peternak itik di desa Argomulyo, Sedayu, Bantul, Yogyakarta. Rimpang kunyit sebagai sumber antioksidan alami dibeli dari pasar lokal di wilayah Yogyakarta.

\section{Preparasi Ekstrak Kurkumin Kunyit}

Proses ekstraksi kunyit dilakukan dengan macerasi dengan alkohol. (Marsono et al., 2004). Rimpang kunyit dicuci, dikupas, diiris dengan ketebalan $1 \mathrm{~mm}$. Selanjutnya diblansing dengan perebusan selanjutnya dibekukan. Sebanyak $300 \mathrm{~g}$ sampel dimasukkan kedalam akuades mendidih 600 ml selama 5 menit, ditiriskan selama 15 menit, dan dikemas dalam kantung plastik untuk disimpan dalam freezer pada suhu- $12^{\circ} \mathrm{C}$ selama 24 jam. Sampel dithawing selama 30 menit, kemudian diaturdi atas nampan dan dimasukkan pengering cabinet pada suhu $57^{\circ} \mathrm{C}$ sampai kadar air sekitar $10 \%$. Kunyit kering, diblender, diayak dengan ayakan 35 mesh, sehingga dihasilkan kunyit bubuk. Ekstraksi kunyit menggunakan cara macerasi dimodifikasi yaitu kunyit bubuk $15 \mathrm{~g}$ dimasukkan Erlenmeyer 250 $\mathrm{ml}$ ditambah alkoho $180 \%$ sebanyak $135 \mathrm{ml}$, ditutup aluminiumfoil, diaduk dengan shaker selama 60 menit, kemudian didiamkan selama 24 jam. Selanjutnya disaring dengan kertas saring Whatman no. 41, sehingga dihasilkan ekstrak kunyit. Ethanol diuapkan menggunakan evaporator vakum pada suhu $40^{\circ} \mathrm{C}$. Ekstrak yang diperoleh digunakan untuk curing daging itik.

\section{Pembuatan Nugget}

Disiapkan daging itik afkir curing. Daging itik segar tanpa tulang dipotong dengan ukuran tertentu yang homogen. Proses curing daging itik dilakukan dengan cara mencampur ekstrak kurkumin kunyit dengan daging itik segar. Variasi rasio daging itik segar/jumlah ekstrak kurkumin adalah 3\% selama 10 menit. Selanjutnya digunakan untuk membuat nugget dengan tahapan mengacu pada SNI (2002) dengan tahapan: penyiapan daging itik, penggilingan, pencampuran dengan bumbu halus, pencetakan, pencelupan dalam adonan breaded, pembekuan dalam freezer, penggorengan. Bumbu yang digunakan adalah garam $2 \%$; STPP $0,3 \%$, terigu; maizena $1,5 \%$; $\mathrm{CMC}$ dan tepung roti, daging $500 \mathrm{~g}$, Tepung tapioka $50 \mathrm{~g}, 1 / 2$ sdt lada bubuk, 1 sdt garam, 1 sdm bawang putih bubuk, $2 \mathrm{sdm}$ bawang merah goreng bubuk dan $20 \mathrm{~g}$ es batu. Ada 3 variasi nugget yaitu original, ditambah brokoli dan ditambah wortel.

\section{Analisis Nugget}

Nugget yang telah jadi selanjutnya dianalisis untuk mengetahui sifat fisik nugget meliputi tekstur menggunakan Test Zwick. Uji warna yang meliputi Lightness (L), Redness (a), dan Yellowness (b) menggunakan alat Minolta Chromameter. Komposisi kimia ditentukan dengan analisis proksimat (AOAC, 1990).

\section{Analisis Data}

Data yang diperoleh dianalisis menggunakan analisis deskriptif antar perlakuan.

Tabel 1. Warna nugget daging itik

\begin{tabular}{lccc}
\hline \multicolumn{1}{c}{ Nugget } & Lightness $(\mathrm{L})$ & Redness $(\mathrm{a})$ & Yellowness $(\mathrm{b})$ \\
\hline Daging itik & 51,1 & 11,70 & 32,57 \\
Daging itik + Wortel & 55,2 & 12,40 & 42,40 \\
Daging Itik + Brokoli & 55,3 & 8,00 & 30,37 \\
\hline
\end{tabular}

*Hasil analisis dua ulangan perlakukan dengan 2 ulangan analisis. 
Tabel 2. Tekstur nugget daging itik

\begin{tabular}{lccc}
\hline \multicolumn{1}{c}{ Nugget } & Chewiness & Deformasi (\%) & Hardness $(\mathrm{g})$ \\
\hline Daging itik & 130,66 & 40,23 & 246,00 \\
Daging itik + Wortel & 347,14 & 43,84 & 252,00 \\
Daging Itik + Brokoli & 1114,86 & 39,16 & 358,75 \\
\hline
\end{tabular}

*Hasil analisis dua ulangan perlakukan dengan 2 ulangan analisis.

\section{HASIL DAN PEMBAHASAN}

\section{Warna Nugget Daging Itik}

Warna nugget hasil penelitian menunjukkan bahwa tingkat kecerahan (L) nugget daging tanpa penambahan sayuran lebih rendah dibanding yang ditambah brokoli dan wortel (Tabel 1). Nilai a terendah pada nugget daging itik + brokoli, hal ini terjadi karena dengan adanya penambahan brokoli menyebabkan warna hijau pada nugget. Nilai b tertinggi pada nugget yang ditambah wortel, karena penambahan wortel menyebabkan warna nugget agak kekuningan. Warna kekuningan pada nugget yang ditambah wortel karena adanya karoten yang terkandung di dalam wortel, sehingga nilai $b$ nya lebih tinggi daripada nugget daging itik saja dan nugget daging itik yang ditambah brokoli.

Selain itu tingginya nilai $L$ dan $b$ juga disebabkan karena dengan adanya suhu pengolahan yang tinggi menunjukkan peningkatan presipitasi myofibrillar dan sarkoplasma protein (Dai et al., 2013), sedangkan penurunan dalam a terjadi karena peningkatan denaturasi mioglobin (Cheah dan Ledward, 1997 dalam Khan et al., 2014a). Hasil penelitian Khan et al. (2014a) menunjukkan bahwa dengan pemanasan yang lebih lama akan meningkatkan nilai $\mathrm{L}$ dan a, tetapi menurunkan nilai b. Lebih lanjut disebutkan oleh Khan et al. (2014b) bahwa pemanasan akan meningkatkan nilai $\mathrm{L}$, a dan $\mathrm{b}$ dari dagi itik bagian dada.

\section{Tekstur Nugget Daging Itik}

Nugget daging itik yang ditambah brokoli mempunyai nilai chewiness dan hardness yang paling tinggi dan Deformasi yang paling rendah dibanding nugget daging itik dan nugget daging itik yang ditambah wortel (Tabel 2). Chewiness atau tingkat kealotan nugget hasil penelitian menunjukkan bahwa nugget daging itik yang ditambah brokoli paling tinggi atau paling alot, sedangkan nugget daging itik tanpa tambahan mempunyai tingkat kealotan yang paling rendah. Hal ini diduga karena yang ditambah brokoli mempunyai serat yang lebih tinggi, sehingga nilai Chewiness tala dan Hardeness paling tinggi. Namun, nugget daging itik yang ditambah brokoli mempunyai nilai Deformasi atau perubahan bentuk karena penekanan yang paling rendah. Hal ini karena nugget daging itik yang ditambah brokoli tekturnya lebih keras, sehingga apabila ditekan tidak banyak berubah.

\section{Komposisi Kimia Nugget Daging Itik}

Hasil analisis kimia nugget daging itik afkir dapat dilihat pada Tabel 3. Hasil analisis menunjukkan bahwa kadar air nugget daging itik paling tinggi disbanding nugget daging itik yang ditambah wortel maupun brokoli. Hal ini disebabkan karena dengan penambahan wortel dan brokoli mengandung serat yang daya ikat airnya rendah. Menurut Fennema (1985) dan Tala (2009) bahwa serat kasar tersusun atas selulosa yang daya ikat airnya rendah. Kadar lemak daging itik yang digunakan $13,35 \% \mathrm{bb}$; air $72,65 \% \mathrm{bb}$.

Kadar lemak nugget daging itik lebih rendah dibanding nugget daging itik yang ditambah wortel dan brokoli. Hal ini diduga karena serat yang terkandung pada wortel dan brokoli menyerap minyak yang digunakan untuk menggoreng lebih banyak. Tala (2009) menyatakan bahwa serat baik yang larut dalam air maupun yang tidak larut, dapat mengikat asam lemak. Namun demikian nugget daging itik memunyai kadar protein yang relatif sama dengan nugget yang ditambah brokoli.

Sedangkan nugget dengan tambahan wortel mempunyai kandungan karbohidrat yang tertinggi disbanding nugget daging itik dan yang ditambah brokoli. Hal ini diduga disebabkan karena wortel termasuk umbi-umbian yang banyak mengandung pati.

\section{KESIMPULAN}

Berdasarkan hasil yang diperoleh maka dapat disimpilkan bahwa nugget daging itik dapat

Tabel 3. Komposisi nugget daging itik

\begin{tabular}{|c|c|c|c|c|c|c|}
\hline \multirow[t]{3}{*}{ Komposisi Kimia } & \multicolumn{6}{|c|}{ Nugget } \\
\hline & \multicolumn{2}{|c|}{ Daging itik } & \multicolumn{2}{|c|}{ Daging itik + Wortel } & \multicolumn{2}{|c|}{ Daging Itik + Brokoli } \\
\hline & $\%(\mathrm{bb})$ & $\%(\mathrm{bk})$ & $\%(\mathrm{bb})$ & $\%(\mathrm{bk})$ & $\%(\mathrm{bb})$ & $\%(\mathrm{bk})$ \\
\hline Air & 54,41 & 79,35 & 39,19 & 64,44 & 43,08 & 56,92 \\
\hline Lemak & 9,10 & 19,96 & 17,37 & 28,56 & 14,73 & 25,88 \\
\hline Protein & 11,85 & 25,99 & 11,24 & 18,48 & 13,42 & 23,58 \\
\hline $\mathrm{Abu}$ & 2,63 & 5,77 & 2,56 & 4,21 & 2,50 & 4,39 \\
\hline $\begin{array}{l}\text { Karbohidrat } \\
\text { (\% by difference) }\end{array}$ & \multicolumn{2}{|c|}{22,01} & \multicolumn{2}{|c|}{29,64} & \multicolumn{2}{|c|}{26,27} \\
\hline
\end{tabular}

*Hasil analisis dua ulangan perlakukan dengan 2 ulangan analisis. 
divariasikan dengan penambahan sayuran antara lain wortel dan brokoli. Dengan penambahan wortel dan brokoli warna nugget lebih menarik, sehingga dan kanddungan gizinya lebih baik.

\section{UCAPAN TERIMA KASIH}

Ucapan terima kasih kami sampaikan kepada Direktorat Pendidikan Tinggi, Kementrian Riset, Teknologi dan Pendidikan Tinggi, yang telah memberikan dana untuk IbM kami tahun 2017.

\section{DAFTAR PUSTAKA}

Ali, M.S., G.H. Kang, H.S. Yang, J.Y. Jeong, Y.H. Hwang, G.B. Park dan S.T. Joo. 2007. A comparison of meat characteristics between duck and chicken breast. Asian-Aust. Journal Animal Science 20: 1002-1006.

AOAC. 1990. Officials Methodsof Analysis Association Official Agricultural Chemistry. Washington D.C.

Baggio, S.R. dan N. Bragagnolo. 2006. Cholesterol oxide, cholesterol, total lipid and fatty acid content in processed meat products during storage. LWT. 39: 513-520.

BPS. 2016. Buku Statistik Peternakan tahun 2016. Badan Pusat statistik. Jakarta.

Chung, Y.C., T. Yokozawa, D.Y. Soung, I.S. Kye, J.K. No and B.S. Baek. 1998. PeroxynitriteScavenging Activity of Green Tea Tannin. Journal of Agricultural and Food Chemistry 46: 4484-4486.

Dai, Y., J. Miao, S. Yuan, Y. Liu, X.M. Li and R.T. Dai. 2013. Color and sarcoplasmic protein evaluation of pork following water bath and ohmic cooking. Meat Science 93(4): 898-905.

Dewi, S.H.C. dan N. Astuti. 2014. Akseptabilitas dan Sifat Daging Itik Afkir Curing Dalam Ekstrak Kurkumin Kunyit Untuk Menghambat Oksidasi Lemak Selama Penyimpanan. Agritech 34(04): 416-421.

Fennema, O. R. 1985. Food Chemestry. Marcell Dekker Inc. New York.

Fujiwara, H., M. Hosokawa, X. Zhou, S. Fujimoto, K. Fukuda, K. Toyoda, Y. Nishi, Y. Fujito, K. Yamada, Y. Yamada, Y. Seino and N. Inagaki. 2008. Curcumin Inhibits Glucose Production in Isolated Mice Hepatocytes. Diabetes Research and Clinical Practice 80: 188-191.

Jayaprakasha, G.K., L. J. Rao and K.K. Sakariah. 2006. Antioxidant activities of curcumin, demethoxycurcumin and bisde methoxycurcumin. Food Chemistry 98: 720724.

Khan, M. A., S. Ali, M. Abid, H. Ahmad, L. Zhang, R. K. Tume and G. Zhou. 2014a. Enhaned texture, yield and safety of ready-to-eat salted duck meat product using a hight pressure-heat process. Journal Innovative Food Science and Emerging Technologies 21: 50-57.

Khan, M. A., S. Ali, M. Abid, H. Ahmad, L. Zhang, R. K. Tume and G. Zhou. 2014b. Improved duck meat quality by application of high pressure and heat: A study af water mobility and compartmentalization, protein denaturation and textural propertis. Food Research International 62: 926-933.

Kikuzaki, H and N. Nakatami. 1994. Antioxidant Effect of Phospholipids on Pirrela Oil. Journal of the American Oil Chemists Society 68: 353357.

Marsono, Y., R. Safitri, dan Z. Noor. 2004. Antioksidan dalam Kacang-kacangan: Aktivitas dan Potensi serta Kemampuannya Menginduksi Pertahanan Antioksidan pada Model Hewan percobaan. Laporan Penelitian Hibah Bersaing XII. Lembaga Penelitian. Yogyakarta.

Matitaputty, P.R. dan Suryana. 2010. Karakteristik Daging itik dan permasalan serta upaya pencegahan off-flavor akibat oksidasi lipida. Wartazoa 20(3): 130-138.

Ruslay, S., F. Abas, K. Shaari, Z. Zainal, Maulidani, H. Sirat, D.A. Israf dan N.H. Lajis. 2007. Characterization of the Components Present in the Active Fractions of Health Gingers (Curcuma Xanthorhiza and Zinziber zerumbet) by HPLC-DAD-ASIMS. Food Chemistry 104:1183-1191.

Sampaio, G.R., T. Saldanna, R.A.M. Soares and E.A.F.S. Torres. 2012. Effect of natural Antioxidant Combinations on Lipid oxidation in Cooked Chicken Meat During Refrigerated Storage. Food Chemistry 135: 1383-1390.

Setyowati, A. dan C. Wariyah. 2012. Mikroenkapsulasi Ekstrak Temulawak, Stabilitas Efek Hipokolesterolemik dan Bioavailabilitasnya. Laporan Penelitian Hibah Bersaing. Universitas Mercu Buana. Yogyakarta. pp. 333-336

SNI. 2002. Standar Nasional Indonesia SNI 0-66832002 Naget Ayam (Chicken Nugget). Badan Standardisasi Nasional. Jakarta.

Tala, Z.Z. 2009. Manfaat Serat bagi Kesehatan. Departemen Ilmu Gizi. Fakultas Kedokteran. Universitas Sumatra Utara. Medan.

Yokozawa, T., T. Nakagawa and K. Kitani. 2002. Antioxidative Activity of Green Tea Polyphenol Cholesterol-Fed Rat. Journal Agricultural and Food Chemistry 50: 3549-3552.

Wanasundara, U.N and F. Shahidi. 1994. Stabilization of canola oil with flavonoids. Food Chemistry 50: 393-396. 